\title{
Monosomy 20 Mosaicism Revealed by Extensive Karyotyping in Blood and Skin Cells: Case Report and Review of the Literature
}

\author{
Ron Hochstenbach ${ }^{a}$ Pieter-Jaap Krijtenburg ${ }^{a} \quad$ Lars T. van der Veken $^{a}$ \\ Jasper van der Smagt ${ }^{a} \quad$ Angelique Roeleveld-Versteegh ${ }^{c}$ Gepke Visser ${ }^{b}$ \\ Paulien Terhala \\ Departments of a Medical Genetics and ${ }^{\mathrm{b}}$ Metabolic Diseases, University Medical Centre Utrecht, Utrecht, and \\ 'Department of Pediatrics, Catharina Hospital, Eindhoven, The Netherlands
}

\section{Key Words}

Asymmetry · Chromosomal mosaicism · Karyotyping ·

Monosomy 20

\begin{abstract}
We describe a 13-year-old boy with developmental delay and proximal muscle weakness who has monosomy 20 mosaicism in blood and skin cells. Because of asymmetric features (difference in foot size, slightly asymmetric intergluteal cleft), we performed extensive cytogenetic studies in peripheral blood and skin. In cultured and uncultured blood lymphocytes, we found 0.9 and $6.5 \%$ of cells with monosomy 20 , respectively. In addition, $3.3 \%$ of uncultured skin fibroblasts and $1.5 \%$ of buccal mucosa cells had monosomy 20 . This is the fifth patient published with this chromosomal condition. These patients show variable clinical features, ranging from normal to delayed motor and speech development. There is no apparent relation between the percentage of monosomic cells as studied in blood and the severity of the phenotype. This could be due to different degrees of mosaicism in the other tissues and organs, which may vary considerably from patient to patient. The degree of monosomy 20 mosaicism in blood is in most patients below the detection limit of microarray technology. Therefore, this work illustrates the
\end{abstract}

necessity of detailed cytogenetic investigation of multiple cell types in developmentally retarded patients with normal microarray results, especially when there are subtle physical indications of chromosomal mosaicism.

(c) 2014 S. Karger AG, Basel

Mosaicism with loss of an entire autosome is extremely rare in live-born humans and has been reported, when studied by karyotyping of cultured peripheral blood lymphocytes, only for the relatively small and gene-poor chromosomes such as 18 [Khalifa et al., 1996; Jackson et al., 2000], 20 [Olinici, 1975; Wurster-Hill et al., 1990; Wallerstein et al., 1991; Stefanou et al., 2006] and 21 [Toral-Lopez et al., 2012]. In addition, fluorescence in situ hybridization (FISH) studies have revealed monosomy for chromosome $15(2.2,2.6$ and $4.6 \%$ in 3 different patients), $16(3.0 \%)$ or $18(2.7 \%)$ in cultured lymphocytes from boys with unexplained autism [Yurov et al., 2007a]. In contrast, no live-born cases have been reported with mosaic loss of the relatively gene-rich chromosomes 17 or 19 [Schinzel, 2001]. For chromosome 22, it cannot be excluded that in published cases the metaphases lacking a chromosome 22 have an undetected translocation involving part of chromosome 22 , as molecular cytogenetic

\section{KARGER}

E-Mail karger@karger.com

www.karger.com/cgr
C 2014 S. Karger AG, Basel

$1424-8581 / 14 / 1443-0155 \$ 39.50 / 0$ 

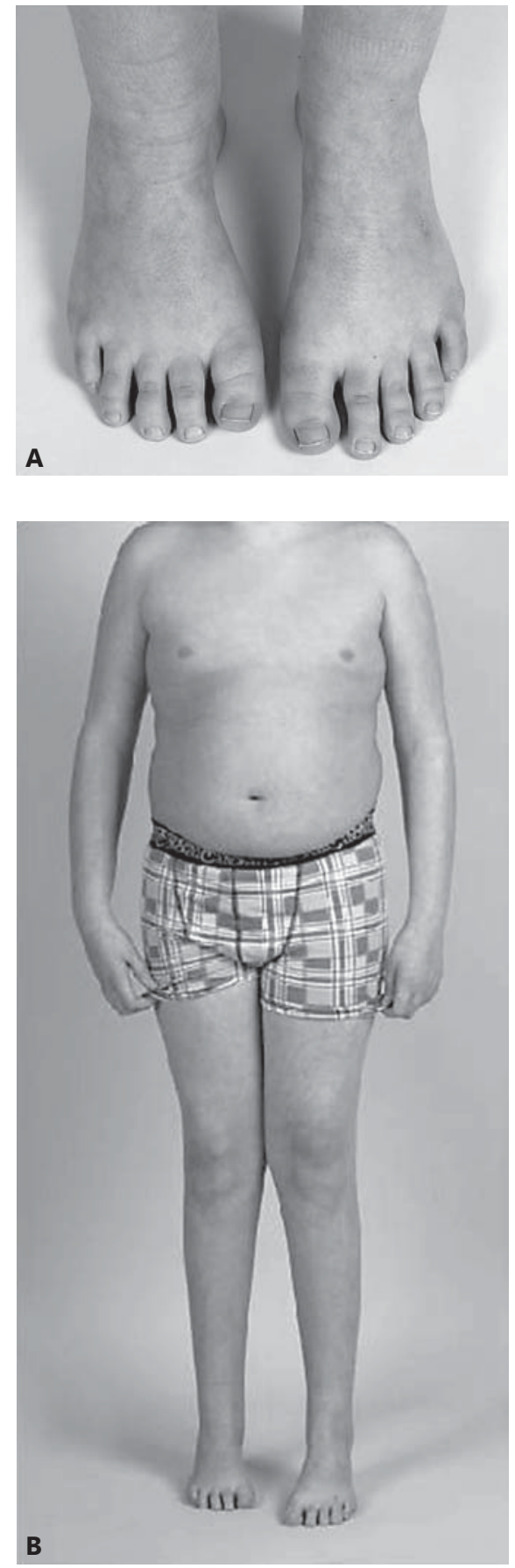

Fig. 1. The patient at 13 years of age. Note the difference in foot size, with the right foot being shorter $(\mathbf{A})$, and the valgus deformity of the knees with underdevelopment of the lower leg musculature (B). studies have not been performed [Pinto-Escalante et al., 1998; Schinzel, 2001].

Here, we present the fifth case of monosomy 20 mosaicism in a boy aged 13 years, presenting with developmental delay, speech delay and unexplained muscle weakness. Cells lacking a chromosome 20 were detected in both uncultured and stimulated lymphocytes from peripheral blood, in cultured skin fibroblasts and in buccal mucosa. We compare our case to those that have been published previously, showing that there is no apparent relation between the proportion of monosomy 20 cells in blood and the severity of the phenotype. We discuss the pitfalls in the detection of a low degree of chromosomal mosaicism in patients with developmental delay and multiple congenital abnormalities.

\section{Clinical Report}

The patient was born at term to healthy nonconsanguineous parents after an uneventful pregnancy. Birth weight was 3,060 g. The Apgar score was 10 after 1 and 5 min. At birth, it was noted that there was a mild inversion of both feet. His motor development has been slow since birth. He was able to sit at the age of 18 months and walked unaided at the age of 22 months. Also his intellectual development was retarded. From the age of 9 years, his cognitive capabilities and articulation seemed to stagnate. At 10 years of age, he scored 54 on the Wechsler Intelligence Scale for Children III, the verbal IQ was below 55 and the performance IQ was 62 . He underwent surgery at the age of 10 years to correct a unilateral nondescended testicle and an inguinal hernia. He showed progressive adipositas, and at 11.5 years of age, the BMI was 21.5 ( $>90$ th percentile). At the age of 12 years, he had several attacks of symptomatic localized epilepsy which were treated with carbamazepine. In addition, there was a general, unexplained proximal muscle weakness and a progressive fatigue after exercise. He was able to walk for about $30 \mathrm{~min}$ and was dependent on a wheelchair for longer distances. Since the age of 13 years he is being treated for hypothyroidism. The patient has a healthy sib. There are no family members who are affected with a neuromuscular disorder. The maternal grandmother had epilepsy until the age of 15 years.

Physical examination at 13 years of age did not reveal facial dysmorphic features. Height was $1.63 \mathrm{~m}(0$ to $-1 \mathrm{SD})$, weight was $57.2 \mathrm{~kg}(+2 \mathrm{SD})$, and head circumference was $52.8 \mathrm{~cm}(-1$ to -2 $\mathrm{SD}$ ). He showed bilateral underdevelopment of the calf muscles, a valgus deformity of the knees and a bilateral pes cavus deformity. His right foot was smaller than the left by 1.5 shoe sizes, but there were no noticeable differences in diameter between both legs (fig. 1). There was a slight asymmetry at the intergluteal cleft. Examination of the skin did not show dermatologic abnormalities. MRI imaging of the brain at age 10 and 13 years was normal. Ophthalmological investigation was normal at the age of 10 years with the exception of a mild dysplastic papilla in the right eye. Handheld dynamometry at 13 years of age showed that his muscle strength was 2 SD below average. An electromyography was per- 
formed and found to be normal. Cardiological examination did not reveal abnormalities. Fragile-X syndrome was excluded by DNA analysis. Metabolic screening of plasma, liquor and urine was normal. There was no CTG-repeat expansion in the DMPK gene, excluding myotonic dystrophy type 1. A muscle biopsy was taken from the right upper leg at age 10 years and showed mild decreased complex $\mathrm{V}$ activity. However, this was not confirmed in skin fibroblasts, also taken from the right upper leg. Heteroduplex analysis of the mitochondrial genome did not provide evidence for mutations, and there were no mutations detected in the coding regions of the $P O L G$ gene.

\section{Materials and Methods}

G-banded metaphases from phytohemagglutinin-stimulated lymphocytes from peripheral blood and from cultured skin fibroblasts were obtained following standard techniques. Two skin biopsies were taken from the right upper leg, the first at age 10 years and the second at age 15. FISH was performed according to standard methods [Liehr and Claussen, 2002] except that after hybridization, the slides were washed twice in $0.4 \times$ SSC, $0.05 \%$ Tween 20 at $72^{\circ} \mathrm{C}$ for $5 \mathrm{~min}$, followed by washes in $2 \times$ SSC, $0.05 \%$ Tween 20 and $4 \times$ SSC, $0.05 \%$ Tween 20 at room temperature for 5 min each. The overlapping BAC probes RP5-858M22, RP11-318C17, RP5974N19, and RP4-790B6 (all located in 20p12.1) were obtained from BlueGnome (Cambridge, UK). The Vysis CEP 20 (centromere, locus D20Z1) and D20S108 probes (located in 20q12) were purchased from Abbott Molecular (Downer's Grove, Ill., USA). The ON dic $(9 ; 20)$ TC probe was supplied by Kreatech (Amsterdam, The Netherlands). Microarray comparative genomic hybridization (CGH) was performed using $105 \mathrm{~K}$ slides (AMADID 019015) from Agilent Technologies (Santa Clara, Calif., USA) following the instructions and using the software provided by the manufacturer. As a reference, we used a mixed pool of DNA from 50 healthy males. Single nucleotide polymorphism (SNP) array analysis was performed using the HumanOmniExpressExome BeadChip SNP array from Illumina (San Diego, Calif., USA) containing 940,000 SNP probes distributed over the entire genome, again according to the instructions of the manufacturer. Analysis of array data was performed using Nexus software from BioDiscovery (Hawthorne, Calif., USA).

\section{Results}

We initially performed oligonucleotide-based arrayCGH and SNP-based array investigations using DNA from peripheral blood. This did not provide evidence for pathogenic segmental aneuploidies, nor for regions of homozygosity larger than $5 \mathrm{Mb}$ (data not shown). Because of the asymmetry of the legs, we performed karyotyping of cultured skin fibroblasts from a biopsy taken from the right upper leg. Two of 50 metaphases investigated showed monosomy 20 (4\%). This prompted additional cytogenetic studies in a second skin biopsy, in mul- tiple blood samples and in buccal mucosa cells (fig. 2). Cultured lymphocytes from 2 independent blood samples showed 0.5 and $1.3 \%$ monosomy 20 , respectively ( $0.9 \%$ on average) (table 1$)$. Probes specific for the centromere of chromosome 20 showed variation in signal intensity in our patient, making detection of monosomy 20 in interphase unreliable. Therefore, we used probes for 2 targets on chromosome 20 for FISH studies of interphase cells, one on the short and one on the long arm, which were visualized using different fluorochromes. Interphase cells with monosomy 20 , as identified by the presence of 1 green and 1 red signal (fig. 2), were detected at a frequency of $6.5 \%$ in uncultured blood cells, $3.3 \%$ in uncultured cells from a second skin biopsy and $1.5 \%$ in buccal mucosa cells (table 1). We did not find cells with trisomy 20 in any of the tissues investigated. As a control, we investigated 250 uncultured blood cells each in 4 normal, healthy individuals. We did not find cells with 1 green and 1 red signal in blood from normal individuals. This makes it very unlikely that the observations in the patient are the result of technical artifacts.

We also investigated whether our patient has an acquired $\operatorname{dic}(9 ; 20)(\mathrm{p} 13.2 ; \mathrm{q} 11.2)$ chromosome in the cells with monosomy 20 . This was done because in $5 \%$ of children with $\mathrm{B}$ cell precursor acute lymphatic leukemia a $\operatorname{dic}(9 ; 20)(\mathrm{p} 13.2 ; \mathrm{q} 11.2)$ chromosome is found. Cells containing such a dic $(9 ; 20)$ chromosome may miss a chromosome 20 [Clark et al., 2000; Zachariadis et al., 2014]. Using the Kreatech ON dic $(9 ; 20)$ TC probe, we did not find evidence for the presence of the $\operatorname{dic}(9 ; 20)$ chromosome in 200 uncultured blood cells. Similarly, in a metaphase with monosomy 20 , there was no evidence for structurally abnormal chromosomes 9 using this probe.

\section{Discussion}

Our knowledge on the contribution of chromosomal aneuploidy mosaicism to human disease has greatly expanded by the application of microarray technology and next-generation sequencing approaches, showing that mosaicism is a widespread phenomenon, also in apparently healthy individuals [Biesecker and Spinner, 2013]. For example, SNP array testing of single neurons derived from induced pluripotent stem cells from healthy persons demonstrated gains and losses of a single, entire chromosome in 11 out of 40 cells studied [McConnell et al., 2013], in line with earlier cytogenetic studies of brain cells from healthy subjects [Rehen et al., 2005; Yurov et al., 2007b; Rodríguez-Santiago et al., 2010]. In contrast, the cases of 
Table 1. Summary of the molecular cytogenetic findings in our patient

\begin{tabular}{|c|c|c|c|c|}
\hline Cell type & $\begin{array}{l}\text { Cell cycle } \\
\text { stage }\end{array}$ & $\begin{array}{l}\text { Cells } \\
\text { investigated, } \mathrm{n}\end{array}$ & Method $^{\mathrm{a}}$ & $\begin{array}{l}\text { Cells with } \\
\text { monosomy 20, \% }\end{array}$ \\
\hline Cultured skin fibroblasts (skin biopsy 1) & metaphase & 50 & GTG-banding & 4.0 \\
\hline Uncultured skin fibroblasts (skin biopsy 2) & interphase & 214 & FISH & 3.3 \\
\hline Cultured skin fibroblasts (skin biopsy 2) & metaphase & 200 & FISH & 0.5 \\
\hline Short-term lymphocyte culture (blood sample 1) & metaphase & 200 & FISH & 0.5 \\
\hline Uncultured lymphocytes (blood sample 2) & interphase & 200 & FISH & 6.5 \\
\hline Short-term lymphocyte culture (blood sample 2) & metaphase & 150 & FISH & 1.3 \\
\hline Buccal mucosa cells & interphase & 200 & FISH & 1.5 \\
\hline
\end{tabular}

${ }^{a}$ FISH was performed using the ON $\operatorname{dic}(9 ; 20)$ TC probe for skin biopsy 2 and a mixture of the Vysis D20S108 probe (located in 20q12) and 4 overlapping BAC probes located in 20p12.1 (RP5-858M22, RP11-318C17, RP5-974N19, and RP4-790B6) for all other specimens.
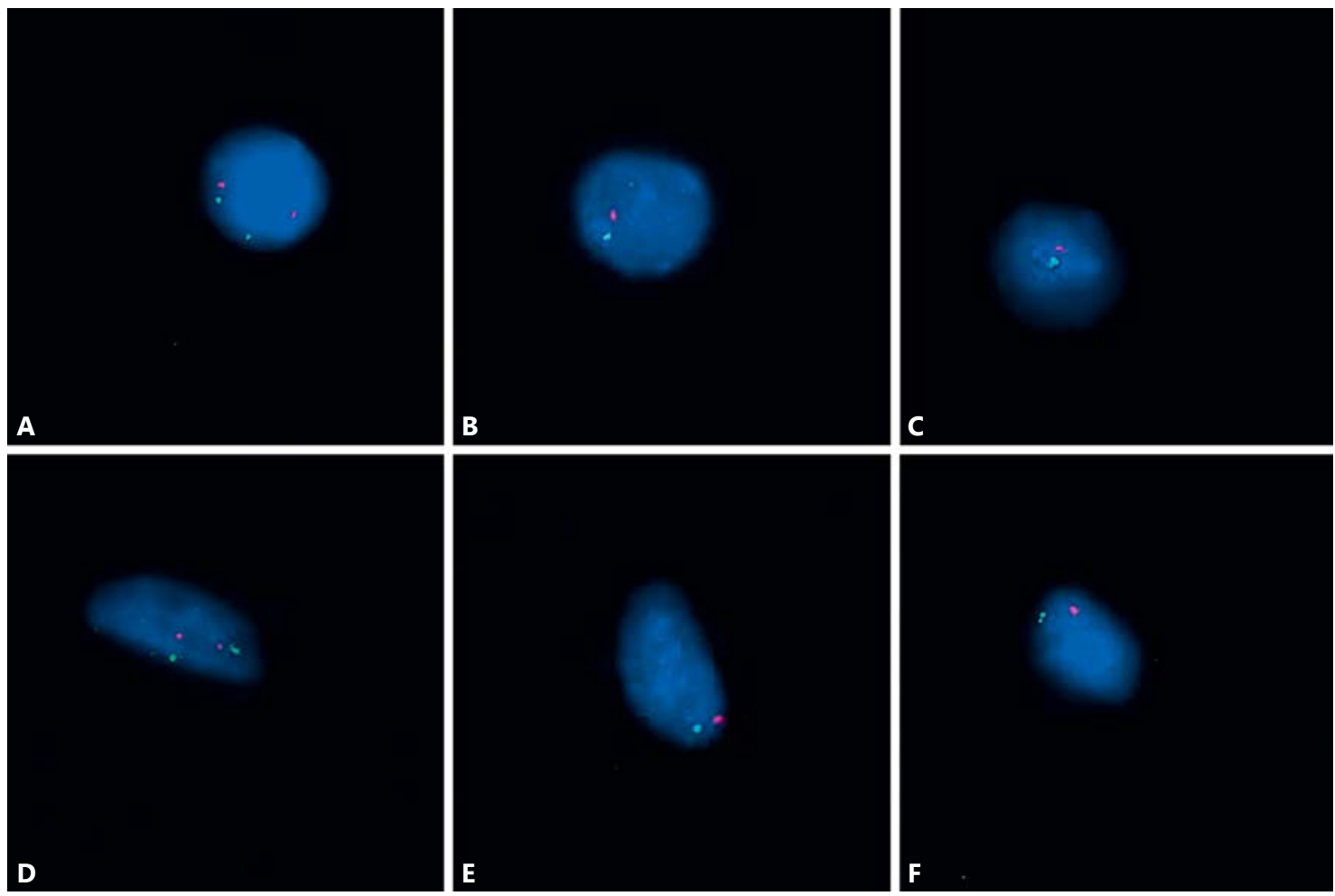

Fig. 2. Representative interphase cells from blood (A-C) and buccal mucosa (D-F) after FISH using a probe mix containing overlapping BACs specific for band 20p12.1 (labeled in green) and the Vysis D20S108 probe located at 20q12 (labeled in red). A and D show normal cells, B, C, E, and $\mathbf{F}$ show cells in which there is only 1 signal with each probe, indicative of monosomy 20.

mosaicism that are detected during routine array-based aneuploidy profiling in diagnostic laboratories represent those with a sufficiently large fraction of abnormal cells in the sample [Cheung et al., 2007; Conlin et al., 2010; Bruno et al., 2011]. Thus, many cases of low-level mosa- icism may go undetected. This implies that there is insufficient knowledge about the significance of chromosomal mosaicism in the etiology of developmental delay and intellectual disability. Sparse reports on low levels of aneuploidy in peripheral blood of children with unexplained 
Table 2. Comparison of the cytogenetic findings in 5 cases with monosomy 20 mosaicism

\begin{tabular}{|c|c|c|c|c|c|}
\hline Cell type & Olinici [1975] & $\begin{array}{l}\text { Wurster-Hill et al. } \\
\text { [1990] }\end{array}$ & $\begin{array}{l}\text { Wallerstein et al. } \\
\text { [1991] }\end{array}$ & $\begin{array}{l}\text { Stefanou et al. } \\
{[2006]}\end{array}$ & Present case \\
\hline $\begin{array}{l}\text { Stimulated } \\
\text { lymphocytes } \\
\text { (metaphase) }\end{array}$ & $\begin{array}{l}25 \% \text { monosomy } 20 \\
1.4 \% \text { trisomy } 20^{\mathrm{a}} \\
\mathrm{n}=71\end{array}$ & $\begin{array}{l}8 \% \text { monosomy } 20 \\
2 \% \text { trisomy } 20 \\
n=50\end{array}$ & $\begin{array}{l}4 \% \text { monosomy } 20 \\
0 \% \text { trisomy } 20 \\
n=100\end{array}$ & $\begin{array}{l}0 \% \text { monosomy } 20 \\
0.5 \% \text { trisomy } 20 \\
\mathrm{n}=200\end{array}$ & $\begin{array}{l}0.5 \% \text { monosomy } 20 \text { (sample } 1) \\
1.3 \% \text { monosomy } 20 \text { (sample } 2) \\
0 \% \text { trisomy } \\
\mathrm{n}=200(1), \mathrm{n}=150(2)\end{array}$ \\
\hline $\begin{array}{l}\text { Uncultured } \\
\text { lymphocytes } \\
\text { (interphase) }\end{array}$ & n.a. & n.a. & n.a. & n.a. & $\begin{array}{l}6.5 \% \text { monosomy } 20 \text { (sample } 2 \text { ) } \\
0 \% \text { trisomy } 20 \\
\mathrm{n}=200^{\mathrm{c}}\end{array}$ \\
\hline $\begin{array}{l}\text { Cultured skin } \\
\text { fibroblasts } \\
\text { (metaphase) }\end{array}$ & n.a. & n.a. & n.a. & $\begin{array}{l}0 \% \text { monosomy } 20 \\
0 \% \text { trisomy } 20 \\
\mathrm{n}=30\end{array}$ & $\begin{array}{l}4 \% \text { monosomy } 20 \text { (sample } 1) \\
0.5 \% \text { monosomy } 20 \text { (sample } 2) \\
0 \% \text { trisomy } 20 \\
\mathrm{n}=50(1), \mathrm{n}=200(2)\end{array}$ \\
\hline $\begin{array}{l}\text { Uncultured skin } \\
\text { fibroblasts } \\
\text { (interphase) }\end{array}$ & n.a. & n.a. & n.a. & n.a. & $\begin{array}{l}3.3 \% \text { monosomy } 20 \text { (sample } 2) \\
0 \% \text { trisomy } 20 \\
\mathrm{n}=214^{\mathrm{c}}\end{array}$ \\
\hline $\begin{array}{l}\text { Buccal mucosa } \\
\text { (interphase) }\end{array}$ & n.a. & n.a. & n.a. & $\begin{array}{l}0 \% \text { monosomy } 20 \\
0 \% \text { trisomy } 20 \\
\mathrm{n}=100^{\mathrm{b}}\end{array}$ & $\begin{array}{l}1.5 \% \text { monosomy } 20 \\
0 \% \text { trisomy } 20 \\
n=200^{c}\end{array}$ \\
\hline $\begin{array}{l}\text { Urine sediment } \\
\text { (interphase) }\end{array}$ & n.a. & n.a. & n.a. & $\begin{array}{l}78 \% \text { monosomy } 20 \\
0 \% \text { trisomy } 20 \\
\mathrm{n}=50^{\mathrm{b}}\end{array}$ & n.a. \\
\hline
\end{tabular}

n.a. = Not analyzed.

a There was 1 metaphase with a supernumerary, unidentified F-group chromosome, which probably was a chromosome 20.

${ }^{\mathrm{b}}$ Interphases were studied by FISH using the D20Z1 centromere-specific probe.

${ }^{c}$ See text for explanation of probes used for interphase FISH.

autism [Yurov et al., 2007a] illustrate the need for more extensive, systematic investigations.

\section{Correlation of Genotype and Phenotype in Monosomy 20 Mosaicism}

Here, we present the fifth case of a live-born patient with mosaicism for monosomy 20 (tables 2,3 ). The phenotype of patients with monosomy 20 mosaicism ranges from clinically normal to delayed motor and intellectual development, with mild dysmorphic signs and asymmetry (table 3). There are no common abnormalities with the noticeable exception of an intergluteal cleft asymmetry in 2 of 5 patients. The abnormal cells were detected in uncultured and cultured peripheral blood and skin cells at low percentages in most cases, varying from 0.5 to $8 \%$ (see tables 2 and 3 for details on the previously published cases). In 2 of the 5 cases both cells with monosomy 20 and trisomy 20 were detected. This suggests that a single, postzygotic, mitotic nondisjunction event occurred, explaining the presence of both abnormal cell lines. It is possible that in the other 3 cases, including our case, ana-

Monosomy 20 Mosaicism in Blood and Skin Cells phase lagging occurred, and that cells with trisomy 20 are absent.

There is no correlation between the percentage of aneuploid cells in cultured lymphocytes and the severity of the phenotype in the 5 patients with monosomy 20 mosaicism (tables 2,3 ) with the highest percentage (25\%) being found in a normal woman [Olinici, 1975]. In general, the relationship between genotype and phenotype in cases of chromosomal mosaicism is not straightforward, and it has even been suggested that the mosaicism of monosomy 20 is a coincidental finding that has no relation to the clinical features [Wurster-Hill et al., 1990]. There are several possible explanations for the apparent lack of a correlation. First, the proportion of aneuploid cells may vary considerably between different tissues of the same patient. Because in most cases of chromosomal mosaicism only peripheral blood is sampled (as in 3 of the 5 cases with monosomy 20 mosaicism), the range of this variation is insufficiently known. In rare instances in which more than 10 different tissues from a single individual were studied, a high variability in percentage of 


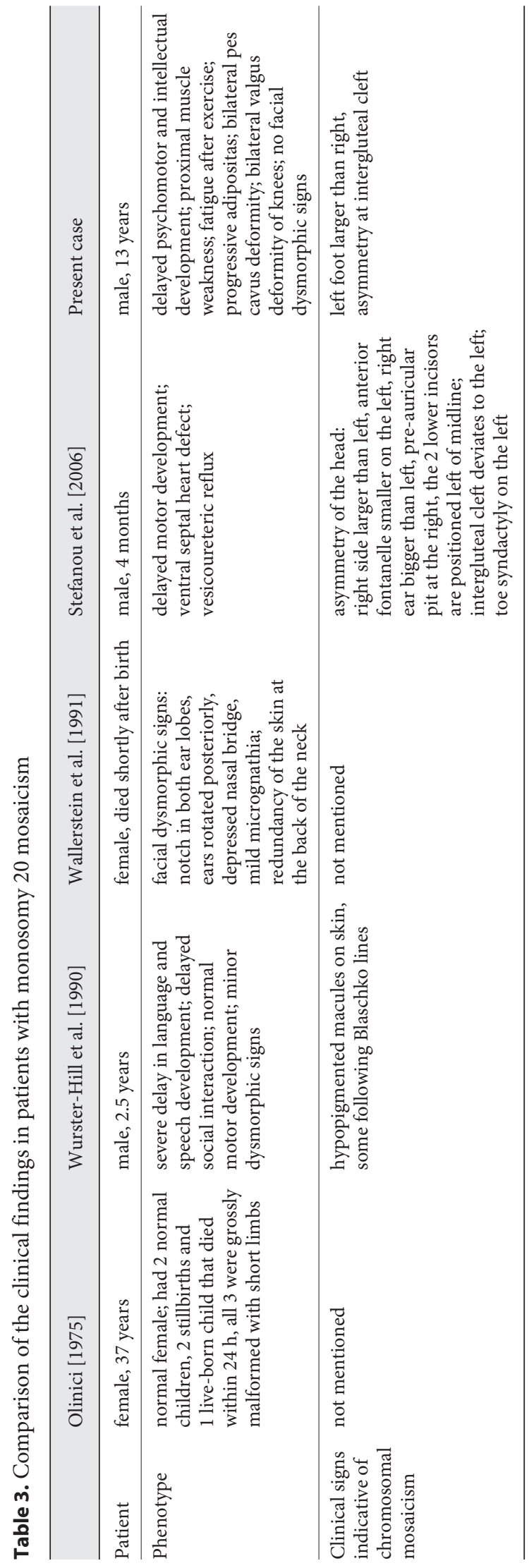

aneuploid cells was found [Fickelscher et al., 2007], indicating that this may contribute to the clinical variability seen between patients with the same mosaic aneuploidy. Indeed, as shown by the patient described by Stefanou et al. [2006], the percentage of monosomy 20 cells may vary from $0 \%$ in buccal mucosa cells to $78 \%$ in urine sediment cells. Second, in cases of monosomy mosaicism, there may be a cryptic cell line with the corresponding trisomy, providing another explanation for phenotypic variability. Additional variation may depend on recessive, mutant alleles on the single, remaining chromosome 20 that become unmasked by the monosomy, and, also, there may be genes on chromosome 20 with a parental origin effect on their expression.

Pitfalls in Detecting Low-Level Aneuploidy Mosaicism

The low number of live-born cases involving autosomal monosomy may not only reflect the impact on viability, but also failure of detection. Mosaicism can be detected by conventional cytogenetic methods if a sufficiently large number of cells have been investigated. Current, internationally accepted, practical guidelines for clinical cytogenetics state that a minimum of 30 metaphases should be inspected [Hastings et al., 2012]. This would be sufficient to exclude an aberrant cell line present in at least $10 \%$ of cells with 95\% confidence [Hook, 1977]. Therefore, when the number of cells studied is lower or when the degree of mosaicism is lower, the mosaicism may go undetected during routine karyotyping based on blood. An additional complicating factor is the possibility of selection against monosomic cells during culture. Because in our patient the percentage of monosomy 20 cells in cultured blood and skin cells is lower than in uncultured cells from the same sample (table 2), counter-selection during culture may indeed have occurred. In addition, low-grade monosomy mosaicism is undetectable using microarraybased techniques [Cheung et al., 2007; Conlin et al., 2010; Bruno et al., 2011]. Professional guidelines for the use of microarrays recommend that laboratories must be capable of detecting $30 \%$ mosaicism in routine diagnostics [Vermeesch et al., 2012]. For microarray-CGH based on bacterial artificial chromosome platforms, the actual detection limit is at $\sim 10 \%$ monosomic cells in the sample [Cheung et al., 2007]. For SNP arrays, detection is possible if there are 7-8\% monosomic cells [Conlin et al., 2010; Bruno et al., 2011]. However, for most of the patients with monosomy 20 mosaicism, the percentage of abnormal cells (as studied in blood) is below these thresholds (table 2), as in our case in which the mosaicism was not detectable by either array-CGH or SNP-based microarray. 
Also, when monosomic and trisomic cells for the same chromosome are present in the sample, as seen for the cases of Olinici [1975] and Wurster-Hill et al. [1990] in blood, they will compensate for each other on both arrayCGH and SNP array platforms, preventing the mosaicism to be detected in the microarray profile.

Failure to detect low-level mosaicism is a matter of concern since microarrays for the detection of genomic imbalances have supplanted karyotyping as the first genomic investigation for patients with developmental delay or multiple congenital anomalies. Many laboratories have stopped performing karyotyping if a microarraybased aneuploidy investigation fails to detect a pathogenic imbalance [Hochstenbach et al., 2009; Miller et al., 2010]. Similarly, whole-exome sequencing, which does not only enable detection of pathogenic point mutations, but also, although limited to gene-containing genomic regions, of pathogenic segmental aneuploidies [de Ligt et al., 2013], may in the near future supplant microarraybased genomic profiling as the first genetic test in patients with developmental delay. It remains to be seen whether whole-exome sequencing has the sensitivity required to detect chromosomal mosaicism.

\section{Instigating Cytogenetic Investigation for Mosaicism}

Our patient shows that it is imperative to perform thorough cytogenetic investigations for chromosomal mosaicism if there is developmental delay in combination with subtle signs of mosaicism, such as growth asymmetry and/or dermatologic anomalies [Pletcher et al., 2007;
Biesecker and Spinner 2013]. Three of the 5 patients with monosomy 20 mosaicism have asymmetric features and/ or skin phenotypes (see table 3). The skin abnormalities may be findings such as multiple types of lesions, multiple lipomas, or numerous hypo- or hyperpigmented areas [Pletcher et al., 2007]. The search for such dermatologic anomalies makes sense, as genes involved in pigmentation are located on virtually each chromosome, including chromosome 20 [Taibjee et al., 2004]. For example, Ousager et al. [2006] found unilateral skin defects in a man with trisomy 16 mosaicism, and Cheung et al. [2007] found Blaschko-linear hyperpigmentation in patients with trisomy 9 and trisomy 14 mosaicism.

We conclude that the contribution of aneuploidy mosaicism to genetic causes of developmental delay is underestimated. Our case demonstrates that both laboratory professionals and clinicians must be aware that, following a normal microarray result, a diagnosis may be missed if cytogenetic investigations to identify cryptic chromosomal mosaicism are not performed, and that clinicians should carefully search for any manifestation of chromosomal mosaicism.

\section{Acknowledgements}

We are grateful to the patient and his parents for their cooperation and to Dr. H. Vles and Dr. A. Besselaar at the Catharina Hospital, Eindhoven, and Dr. A. Buijs at the Department of Medical Genetics, Utrecht, for helpful discussions.

\section{References}

Biesecker LG, Spinner NB: A genomic view of mosaicism and human disease. Nat Genet 14: 307-320 (2013).

Bruno DL, White SM, Ganesamoorthy D, Burgess T, Butler K, et al: Pathogenic aberrations revealed exclusively by single nucleotide polymorphism (SNP) genotyping data in 5000 samples tested by molecular karyotyping. J Med Genet 48:831-839 (2011).

-Cheung SW, Shaw CA, Scott DA, Patel A, Sahoo T, et al: Microarray-based CGH detects chromosomal mosaicism not revealed by conventional cytogenetics. Am J Med Genet Part A 143A:1679-1686 (2007).

Clark R, Byatt SA, Bennett CF, Brama M, Martineau $\mathrm{M}$, et al: Monosomy 20 as a pointer to dicentric $(9 ; 20)$ in acute lymphoblastic leukemia. Leukemia 14:241-246 (2000).
Conlin LK, Thiel BD, Bonnemann CG, Medne L, Ernst LM, et al: Mechanisms of mosaicism, chimerism and uniparental disomy identified by single nucleotide polymorphism array analysis. Hum Mol Genet 19:1263-1275 (2010).

de Ligt J, Boone PM, Pfundt R, Vissers LELM, Richmond T, et al: Detection of clinically relevant copy number variants with wholeexome sequencing. Hum Mutat 34:14391448 (2013).

Fickelscher I, Starke H, Schulze E, Ernst G, Kosyakova N, et al: A further case with a small supernumerary marker chromosome (sSMC) derived from chromosome 1 - evidence for high variability in mosaicism in different tissues of sSMC carriers. Prenat Diagn 27:783785 (2007).
Hastings R, Howell R, Bricarelli FD, Kristoffersson U, Cavani S: Specific constitutional cytogenetic guidelines. A common European framework for quality assessment for constitutional, acquired and molecular cytogenetic investigations. E.C.A. Newsletter 30:11-19 (2012).

Hochstenbach R, van Binsbergen E, Engelen J, Nieuwint A, Polstra A, et al: Array analysis and karyotyping: workflow consequences based on a retrospective study of 36,325 patients with idiopathic developmental delay in the Netherlands. Eur J Med Genet 52:161-169 (2009).

Hook EB: Exclusion of chromosomal mosaicism: tables of $90 \%, 95 \%$, and $99 \%$ confidence limits and comments on use. Am J Hum Genet 29: 94-97 (1977).

-Jackson KE, Tsien F, Marble M: Phenotypic features in a boy with monosomy 18 mosaicism. Am J Med Genet 95:229-232 (2000).
Monosomy 20 Mosaicism in Blood and Skin Cells
Cytogenet Genome Res 2014;144:155-162 DOI: $10.1159 / 000369606$ 
Khalifa MM, Yamashiro H, Duncan AM, Hefferon M, Martin AE: A female with monosomy 18 mosaicism: a previously undescribed chromosome abnormality. Clin Genet 49:318-320 (1996).

Liehr T, Claussen U: FISH on chromosome preparations of peripheral blood, in Rautenstrauss B, Liehr T (eds): FISH Technology, pp 73-81 (Springer Verlag, Berlin 2002).

McConnell MJ, Lindberg MR, Brennand KJ, Piper JC, Voet T, et al: Mosaic copy number variation in human neurons. Science 342:632637 (2013).

- Miller DT, Adam MP, Aradhya S, Biesecker LG, Brothmann AR, et al: Consensus statement: chromosome microarray is a first-tier clinical diagnostic test for individuals with developmental disabilities or congenital anomalies. Am J Hum Genet 86:749-764 (2010).

-Olinici CD: Report of a case of 46,XX/45,XX,-20 mosaicism. Ann Genet 18:206-208 (1975).

- Ousager LB, Brandrup F, Brasch-Andersen C, Erlendsson A: Skin manifestations in a case of trisomy 16 mosaicism. Br J Dermatol 154: 172-176 (2006).

-Pinto-Escalante D, Ceballos-Quintal JM, Castillo-Zapata I, Canto-Herrera J: Full mosaic monosomy 22 in a child with DiGeorge syndrome facial appearance. Am J Med Genet 76 : 150-153 (1998).
Pletcher BA, Toriello HV, Noblin SJ, Seaver LH, Driscoll DA, et al: Indications for genetic referral: a guide for healthcare providers. Genet Med 9:385-389 (2007).

Rehen SK, Yung YC, McGeight MP, Kaushal D, Yang AH, et al: Constitutional aneuploidy in the normal human brain. J Neurosci 25:21762180 (2005).

Rodríguez-Santiago B, Malats N, Rothman N, Armengol L, Garcia-Closas M, et al: Mosaic uniparental disomies and aneuploidies as large structural variants of the human genome. Am J Hum Genet 87:129-138 (2010).

Schinzel A: Catalogue of Unbalanced Chromosome Aberrations in Man (Walter de Gruyter, Berlin 2001)

-Stefanou EG, Crocker M, Boon A, Stewart H: Cryptic mosaicism for monosomy 20 identified in renal tract cells. Clin Genet 70:228-232 (2006).

Taibjee SM, Bennett DC, Moss C: Abnormal pigmentation in hypomelanosis of Ito and pigmentary mosaicism: the role of pigmentary genes. Br J Dermatol 151:269-282 (2004).
Toral-Lopez J, Gonzalez-Huerta LM, Cuevas-Covarrubias SA: Complete monosomy mosaic of chromosome 21: case report and review of the literature. Gene 510:175-179 (2012).

Vermeesch JR, Brady PD, Sanlaville D, Kok K, Hastings RJ: Genome-wide arrays: quality criteria and platforms to be used in routine diagnostics. Hum Mutat 33:906-915 (2012).

Wallerstein DF, Wallerstein R, Watkins C: Low frequency of monosomy 20 mosaicism in a liveborn infant with minor dysmorphic features. Lancet 337:803-804 (1991).

Wurster-Hill DH, Moeschler JM, Park JP, McDermet MK: Mosaicism for monosomy 20 in a 30-month-old boy. Am J Hum Genet 47:A44 (1990).

Yurov YB, Vorsanova SG, Iourov IY, Demidova IA, Beresheva AK, et al: Unexplained autism is frequently associated with low-level mosaic aneuploidy. J Med Genet 44:521-525 (2007a).

- Yurov YB, Iourov IY, Vorsanova SG, Liehr T, Koloti $\mathrm{AD}$, et al: Aneuploidy and confined chromosomal mosaicism in the developing human brain. PLoS One 6:e558 (2007b).

-Zachariadis V, Schoumans J, Ofverholm I, Barbany G, Halvardsson E, et al: Detecting dic(9; 20)(p13.2;q11.2)-positive B-cell precursor acute lymphoblastic leukemia in a clinical setting using fluorescence in situ hybridization. Leukemia 28:196-198 (2014). 